\title{
Multiple Breeds and Countries' Predictions of Mineral Contents in Milk from Milk Mid-Infrared Spectrometry
}

\author{
Octave S. Christophe ${ }^{1}{ }^{\circledR}$, Clément Grelet $^{1}\left(\mathbb{D}\right.$, Carlo Bertozzi $^{2}$, Didier Veselko ${ }^{3}$, Christophe Lecomte ${ }^{4}$, \\ Peter Höeckels ${ }^{5}$, Andreas Werner ${ }^{6}$, Franz-Josef Auer ${ }^{7}$, Nicolas Gengler ${ }^{8} \mathbb{C}$, Frédéric Dehareng $1, * \mathbb{}$ \\ and Hélène Soyeurt ${ }^{8}$ (D)
}

check for updates

Citation: Christophe, O.S.; Grelet, C.; Bertozzi, C.; Veselko, D.; Lecomte, C.; Höckels, P.; Werner, A.; Auer, F.-J.; Gengler, N.; Dehareng, F.; et al. Multiple Breeds and Countries' Predictions of Mineral Contents in Milk from Milk Mid-Infrared Spectrometry. Foods 2021, 10, 2235. https://doi.org/10.3390/ foods10092235

Academic Editor: Maria D. Guillen

Received: 23 August 2021

Accepted: 17 September 2021

Published: 21 September 2021

Publisher's Note: MDPI stays neutral with regard to jurisdictional claims in published maps and institutional affiliations.

Copyright: (c) 2021 by the authors. Licensee MDPI, Basel, Switzerland. This article is an open access article distributed under the terms and conditions of the Creative Commons Attribution (CC BY) license (https:// creativecommons.org/licenses/by/ $4.0 /)$
1 Walloon Agricultural Research Center (CRA-W), 24 Chaussée de Namur, 5030 Gembloux, Belgium; o.christophe@cra.wallonie.be (O.S.C.); c.grelet@cra.wallonie.be (C.G.)

2 Elevéo Asbl, AWE Group, 4, Rue des Champs Elysées, 5590 Ciney, Belgium; cbertozzi@awenet.be

3 Comité du Lait de Battice Route de Herve 104, 4651 Battice, Belgium; didier.veselko@comitedulait.be

4 France Conseil Elevage, Maison du Lait, 42 Rue de Chateaudun, 75009 Paris, France; christophe.lecomte@france-conseil-elevage.fr

5 Landeskontrollverband Nordrhein-Westfalen e.V., Bischofstraße 85, 47809 Krefeld, Germany; hoeckels@lkv-nrw.de

6 LKV Baden Württemberg, Heinrich-Baumann Str. 1-3, 70190 Stuttgart, Germany; awerner@lkvbw.de

7 LKV Austria Gemeinnützige GmbH, Dresdnerstr. 89/B1/18, 1200 Wien, Austria; Franz-Josef.Auer@lkv-austria.at

8 Gembloux Agro-Bio Tech, TERRA Teaching and Research Centre, University of Liège, 5030 Gembloux, Belgium; nicolas.gengler@uliege.be (N.G.); hsoyeurt@uliege.be (H.S.)

* Correspondence: f.dehareng@cra.wallonie.be

\begin{abstract}
Measuring the mineral composition of milk is of major interest in the dairy sector. This study aims to develop and validate robust multi-breed and multi-country models predicting the major minerals through milk mid-infrared spectrometry using partial least square regressions. A total of 1281 samples coming from five countries were analyzed to obtain spectra and in ICP-AES to measure the mineral reference contents. Models were built from records coming from four countries ( $n=1181)$ and validated using records from the fifth country, Austria $(n=100)$. The importance of including local samples was tested by integrating 30 Austrian samples in the model while validating with the remaining 70 samples. The best performances were achieved using this second set of models, confirming the need to cover the spectral variability of a country before making a prediction. Validation root mean square errors were $54.56,63.60,7.30,59.87$, and $152.89 \mathrm{mg} / \mathrm{kg}$ for $\mathrm{Na}, \mathrm{Ca}, \mathrm{Mg}, \mathrm{P}$, and $\mathrm{K}$, respectively. The built models were applied on the Walloon milk recording large-scale spectral database, including 3,510,077. The large-scale predictions on this dairy herd improvement database provide new insight regarding the minerals' variability in the population, as well as the effect of parity, stage of lactation, breeds, and seasons.
\end{abstract}

Keywords: milk; mid-infrared; minerals

\section{Introduction}

Measuring the mineral composition of milk is of major interest in the dairy sector as they play an important role for human and animal health, and also due to milk's technological properties and the environmental impact of dairy farming. The main minerals in bovine milk are calcium $(\mathrm{Ca}$, around $1200 \mathrm{mg} / \mathrm{kg})$, potassium $(\mathrm{K}$, around $1500 \mathrm{mg} / \mathrm{kg})$, sodium ( $\mathrm{Na}$, around $350 \mathrm{mg} / \mathrm{kg}$ ), magnesium $(\mathrm{Mg}$, around $90 \mathrm{mg} / \mathrm{kg}$ ), and phosphorus $(\mathrm{P}$, around $950 \mathrm{mg} / \mathrm{kg}$ ) [1]. Among others, calcium in the human diet affects the rigidity of skeletal and neuromuscular function, enzyme-mediated processes, and blood clotting [2], as well as arterial hypertension, colon cancer [3,4], and regulation of body weight and body fat $[4,5]$. Potassium plays a fundamental role in the maintenance of homoeostasis and participates in the transmission of nervous impulses, muscle contraction, and regulation of 
blood pressure [6]. An increase of dietary potassium, coupled with a reduction of dietary $\mathrm{Na}$, limits the risk of hypertension [7]. Uribarri and Calvo (2014) [8] claimed that high dietary P intake, although considered an essential nutrient, is a risk factor for bone and cardiovascular diseases.

Besides health aspects, $\mathrm{Ca}$ and $\mathrm{P}$ are essential components of casein micelles $[9,10]$ and are consequently directly involved in the milk coagulation process. In particular, they have a strong influence on the ability of milk to coagulate and on the final consistency of the coagulum [11].

The mineral profile of milk can also be considered as a biomarker for cow management, especially regarding udder health. Both $\mathrm{Na}$ and $\mathrm{K}$ in milk are affected by ruptured mammary epithelia and alteration of blood-milk barriers induced by mastitis [12-14]. Basin et al. [15] also observed that a higher risk of clinical mastitis was genetically strongly associated with greater variation over the lactation of the contents in milk of $\mathrm{Na}$ and $\mathrm{Ca}$ predicted from milk mid-infrared (MIR) spectrometry. $\mathrm{K}$ and Na were also mentioned to be associated with metabolic disorders, such as mastitis, alkalosis, and acidosis [13].

Finally, the P content in milk could be used in order to better manage the environmental impact of dairy herds. Indeed, through effluents, dairy farms are participating in the release of phosphate in surface and ground water resources [16], promoting eutrophication of aquatic systems. This results in the bloom of aquatic plants, growth of algae, and depletion of dissolved oxygen [17]. In Europe, the EU Nitrates Directive (European Council, 1991) is the core regulation to limit nutrient loss from farming systems. To comply, countries may apply drastic plans for the dairy sector, such as the phosphate regulation plan in the Netherlands leading to a reduction by $11 \%$ of the number of dairy cows [18]. Therefore, measuring milk $\mathrm{P}$ would allow better insight on the needs of cow $\mathrm{P}$ and $\mathrm{P}$ efficiency in order to reduce the environmental impact.

Consequently, there is a need to assess the mineral profile in milk through costeffective and large-scale methods, such as milk MIR spectrometry. From 2009 and the first study conducted by Soyeurt et al. [19], numerous studies were carried out to develop MIR models predicting milk minerals [20-26]. For wide, large-scale use by dairy herd improvement (DHI) centers and dairy industries, such models need to be robust to provide accurate and reproducible predictions in various conditions. To achieve this objective, large variability in the calibration dataset both regarding the reference values and the spectral data is essential $[27,28]$. For this reason, the first objective and the novelty of this work is to develop MIR models predicting the mineral content of milk from a large and variable dataset, including records coming from several countries, breeds, seasons, diets, and MIR spectrometers. No models presented in the literature [20-26] exhibit a multi-country approach, and the models presented could allow a wide range of utilization for the farmer and could be used for all the countries present in the calibration set. The second objective was to test the models on a country-independent validation dataset and to evaluate the impact of including local samples in the calibration dataset. The third objective was to study the different correlations between minerals and other traits to confirm the potential interest of those predictions as animal health or milk technological indicators. Finally, the built models were applied on the millions of spectra present in the Walloon DHI database managed by the Walloon Breeding Association in order to get more insight on the behavior of those predicted mineral contents in milk from a large-scale population of cows.

\section{Materials and Methods}

\subsection{Data}

From 2005 to 2020, approximately 3000 milk samples were collected from individual cows in five different countries (Belgium, France, Germany, Luxembourg, and Austria). Those samples were collected by local DHI centers with the objective to maximize the variability, by sampling local specificities, diets, breeds, and management systems. Based on this methodology, the collected samples represented 13 dairy breeds: Abondance 
(ABO), Aubrac (AUB), dual-purpose Belgian Blue (BBL), Brown Swiss (BSW), Fleckvieh (FLE), Holstein-Friesian (HOL), Jersey (JER), Meuse-Rhine-Yssel-type Red and White (MRY), Montbéliarde (MON), Normande (NMD), Salers (SAL), Simmental (SIM), and Tarentaise (TAR).

As the measurement of the mineral content by chemical analysis is costly and timeconsuming, we try to limit the number of analysis. To gather robustness to the model while limiting the chemical analysis, only half of those samples were selected based on their spectral variability. Starting from the model developed by Soyeurt et al. [19], new samples were added iteratively, by picking the most spectrally different samples. The sample selection was based on the standardized Mahalanobis distance, also called the Global $\mathrm{H}$ distance $(\mathrm{GH})$, and the neighboring $\mathrm{H}$ distance $(\mathrm{NH})$ [27]. This led to a dataset of 1281 selected samples, with 502 samples from Belgium and Luxembourg, 388 samples from France, 291 samples from Germany, and 100 samples from Austria.

All milk samples were collected following the guidelines edited by the International Committee for Animal Recording and with the use of a preservative to ensure the stability of milk physico-chemical properties before analysis. To be representative of the real routine methods, the samples coming from different countries were preserved using the antimicrobial and concentration classically used within each local milk recording. In the majority of cases, bronopol was used with a concentration of $0.03 \%$, in some places with an addition of Kathon ${ }^{\mathrm{TM}}$ CG (mix of Methylchloroisothiazolinone (CMIT) and Methylisothiazolinone (MIT); Dow Chemical Company, Midland, MI, USA) at 0.003\%. For 136 samples, sodium azide tabs were used as antimicrobial. As the use of sodium azide distorted the Na analysis because ICP-AES took into account the sodium concentration contained in the antimicrobial product, we chose to remove the associated 136 Na reference values. MIR spectra were generated by spectrometers from the analysis of fresh milk samples by the local milk laboratories. The different spectrometers used were FT6000, FT+ and FT7 (Foss, Hillerød, Denmark), FTS (Bentley, Chaska, MN, USA), and Standard Lactoscope FT-MIR automatic (PerkinElmer, Waltham, MA, USA). To harmonize the spectral information, the spectral data were standardized into a common format using the piece-wise standardized method (PDS) following the OptiMIR project protocol [29]. Since this standardization method was developed in 2011, only the spectra recorded after this date were standardized (i.e., the last 986 out of 1281). However, the remaining raw spectra (not standardized) were all generated by Foss spectrometers based on which the common format was established.

\subsection{Reference Analysis}

The inductively coupled plasma-atomic emission spectroscopy (ICP-AES) (Horiba Jobin Yvon GmbH, Bensheim, Germany) was utilised as the reference method for the determination of the mineral content in milk. The dispersive system was a Czerny-Turner monochromator with a focal distance of $1 \mathrm{~m}$. The wavelength pathways ranged from 120 to $800 \mathrm{~nm}$.

Humidification of argon was used, as well as a peristaltic pump. The integration parameters were strictly the same as described by Soyeurt et al. [19]: nebuliser gas flow $=0.75 \mathrm{~min}^{-1}$; pressure of nebuliser $=3$ bar; Rf power $=1100 \mathrm{~W}$; fixed time of rising $=60 \mathrm{~s}$; fast-speed rinsing pumps; time of transfer $=15 \mathrm{~s}$; time of stabilisation $=45 \mathrm{~s}$; fast speed of transfer pump; synchronisation time $=0 \mathrm{~s}$; and normal speed of pumps $=20 \mathrm{~m} / \mathrm{s}$. The wavelength for the determination of $\mathrm{Na}, \mathrm{Ca}, \mathrm{Mg}$, P, and $\mathrm{K}$ were 590, 318, 279, 178, and $766 \mathrm{~nm}$, respectively.

As described by Soyeurt et al. [19], the use of a previous mineralisation stage of the sample was ignored in order to avoid any mistakes from the losing sample. A dilution method described by Murcia et al. [30] was chosen thanks to the conclusion by Soyeurt et al. [19]. Direct quantification was performed using a dilution factor milk sample of 100. To improve the repeatability of the measurement, an addition of $1 \mathrm{~mL}$ surfactant Triton X-100 (Polyethylene glycol tert-octylphenyl ether and Sigma-Aldrich Birnem, Belgium) concentrated at $1 \mathrm{M}$ was performed. 
Therefore, the ICP-AES technique was carried out without mineralization to perform a direct quantification on diluted milk samples (1:100).

In addition, the removal of $\mathrm{Na}$ values due to the use of sodium azide tabs, 30, 0, 43, and 35 samples were rejected for $\mathrm{Ca}, \mathrm{Mg}, \mathrm{P}$, and $\mathrm{K}$, respectively, principally because of low repeatability induced by poor sample preservation or analytical issues.

\subsection{Modelling}

The pretreatments consisted of applying a first derivative with a gap of five wavenumbers and a normalization of variables (autoscale). Then, to limit the presence of noisy areas, the spectral area selected was like the region selected by Grelet et al. [27]: 968.1 to $1577.5 \mathrm{~cm}^{-1}, 1731.8$ to $1762.6 \mathrm{~cm}^{-1}, 1781.9$ to $1808.9 \mathrm{~cm}^{-1}$, and 2831.0 to $2966.0 \mathrm{~cm}^{-1}$. This represents the 212 first-derivative spectral points.

Calibration and cross-validation were performed on dataset-merging records coming from Belgium, Luxembourg, France, and Germany (maximum of 1181 samples). Calibrations were performed with partial least square (PLS) regression. Cross-validations were performed using 10 folds randomly constituted. During those cross-validations, samples with an absolute residual higher than 2.5 times the standard deviation of the global residuals were recognized as outliers and excluded from the models [31,32]. The number of latent variables (LV) were selected visually through the point of break of root mean square error of cross-validation (RMSEcv) slope. In other words, at this break point, adding a new $\mathrm{LV}$ did not substantially reduce the RMSEcv. However, a maximum of $16 \mathrm{LV}$ was set to avoid overfitting [33].

In order to have a fully independent validation, the records coming from Austria were used to validate the developed models, as those samples came from a completely different environment; in particular, some of them were collected in the area of the Alps mountains with associated typical diets. All models were evaluated through the calculation of RMSE, $\mathrm{R}^{2}$, and the ratio of performance to deviation (RPD), after both cross-validation and validation processes. As the RPD aims to combine the variability of the model (i.e., the SD of the calibration dataset) and the accuracy of predictions (i.e., the RMSE in the cross-validation and validation steps), it was calculated using the SD of the calibration dataset and the RMSE in the cross-validation and validation steps.

Then, in order to check the robustness of the forecasts (i.e., to assess the relevancy of having data coming from a country where we want to make a prediction), a second calibration set was created by adding, to the first training set, 30 randomly selected Austrian samples. The modeling process was exactly the same and the validation was performed on the 70 remaining Austrian samples to validate the model with four countries (Belgium, Luxemburg, France, and Germany) and the other one with the Austrian data included. Finally, all the samples were merged, and a third calibration dataset was created by randomly selecting $80 \%$ of randomly selected samples from the entire dataset (1024 of 1281 samples). Models were then validated with the remaining $20 \%$ of records.

Another metric was used to evaluate our models. The concordance correlations coefficient (CCC) allowed us to underline potential slope or bias problems in the development of the mineral models. The CCC was calculated through the Equation (1).

$$
C C C=\frac{2 \rho \sigma_{x} \sigma_{y}}{\sigma_{x}^{2}+\sigma_{y}^{2}\left(\mu_{x}+\mu_{y}\right)^{2}}
$$

where $x$ is referring to the reference, and $y$ to the predicted values; $\mu$ are the means, $\sigma$ is the covariance, and $\rho$ is the correlation coefficient between the reference and the predicted.

The different percentage of model improvement was calculated as stated in Equation (2).

$$
\%=\frac{\left(X-X_{\text {aust }}\right)}{X_{\text {aust }}},
$$


where $X$ can be the RMSECV, RMSEP, or RPD of model without any Austrian data included and $X_{\text {aust }}$ is with 30 Austrians included.

All computations were carried out with the PLS toolbox v. 4.11 (Eigenvector Research, Inc.,Wenatchee, WA, USA), Winisi software (version 4.6; Foss, Hillerød, Denmark), and scripts developed in Matlab v7.5.0 (The Mathworks, Inc., Natick, MA, USA).

\subsection{Relationships with Traits Related to Animal Health and Milk Technological Properties}

In order to assess the relevancy of considering major minerals as health indicators or milk technological indicators, the reference mineral contents were correlated with the MIR-based predictions known to be related to those issues. These traits are listed in Table 1 with their corresponding RPD. Moreover, in order to compare the relevancy of mineral predictions compared to the reference values, the mineral predictions were also correlated with the traits mentioned in Table 1.

Table 1. Equations predicting traits related to animal health and milk technological properties.

\begin{tabular}{|c|c|c|c|c|c|}
\hline Traits & $\begin{array}{c}\text { Related } \\
\text { Parameter }\end{array}$ & N Records & Country & RPDcv & Author \\
\hline Casein $(\mathrm{g} / 100 \mathrm{~g})$ & Cheese process & 996 & 1 & 4.46 & Unpublished \\
\hline Citrate (mmol/L) & Energy balanced & 566 & 4 & 3.21 & Grelet et al. (2016) [32] \\
\hline NAGase (Units/L) & Mastitis & 377 & 6 & 1.41 & Unpublished \\
\hline LDH (Units/L) & Mastitis & 305 & 6 & 1.21 & Unpublished \\
\hline Lactoferrin $(\mathrm{mg} / \mathrm{L})$ & Mastitis & 2654 & 4 & 1.43 & Soyeurt et al. (2020) [34] \\
\hline $\mathrm{RCT}(\mathrm{s})$ & Cheese process & 337 & 1 & 1.54 & Colinet et al. (2015) [35] \\
\hline k20 (s) & Cheese process & 337 & 1 & 1.24 & Colinet et al. (2015) [35] \\
\hline a30 (s) & Cheese process & 337 & 1 & 1.54 & Colinet et al. (2015) [35] \\
\hline Fresh ILCY (g curd/100 g) & Cheese process & 337 & 1 & 1.91 & Colinet et al. (2015) [35] \\
\hline
\end{tabular}

NAGase: $N$-acetyl- $\beta$-D-glucosaminidase; LDH: lactose dehydrogenase RCT: rennet coagulation time; k20: curd-firming time; a30: curd firmness 30 min after rennet addition; ILCY: Individual laboratory cheese yield.

The Pearson correlations between minerals and traits were calculated using the Equation (3). Two sorts of correlations are calculated in this study. The correlations correspond to the link between the reference and predicted minerals and predicted traits.

$$
\rho_{x, y}=\frac{\sigma_{(x, y)}}{S D_{x} S D_{y}},
$$

where $x$ is referring to mineral traits (reference or predicted) and $y$ to other traits; $\rho$ are the correlations, $\sigma$ is the covariance between $x$ and $y$, and $S D$ is the standard deviation.

\subsection{Large-Scale Phenotyping}

The developed MIR predictive models were finally applied to the DHI spectral database related to the southern part of Belgium and managed by the Walloon Breeding Association (Awé, Ciney, Belgium). This database included 3,510,077 spectra from 235,355 different cows and 1344 herds recorded from 1 January 2012 to 4 March 2020. Records had days in milk (DIM) ranging from 5 to 365 days, and a parity up to 18 and concerning 16 different cows breeds. This large-scale prediction allowed us to obtain information about the evolution of milk mineral prediction following the stage of lactation, month of tests, and parity. These effects were assessed by computing descriptive statistics.

\section{Results and Discussion}

\subsection{Reference Dataset}

The descriptive statistics of the entire dataset are mentioned in Table 2. The various numbers of samples per mineral is related to the erroneous ICP-AES analysis, as mentioned previously. The main purpose of this study was to establish robust models who can be applied on a large application scale. Compared to the current study, the models published 
in the literature $[19,23]$ had a different standard deviation and mean. Indeed, these metrics vary according to the sampling.

The models presented by Toffanin et al. [20] exhibited relatively few differences in mean concentration for $\mathrm{Ca}$ and $\mathrm{P}(0.84 \%$ and $-5.84 \%)$ with our models. A higher average was especially found with the mineral models presented by Visentin et al. [23] (12.45\%, $17.42 \%, 29.60 \%, 1.93 \%,-0.86 \%$ for $\mathrm{Na}, \mathrm{Ca}, \mathrm{Mg}, \mathrm{P}$ and $\mathrm{K}$, respectively). The sampling was carried out in the South Tyrol region where cattle are mainly used for cheese production.

Another difference is clearly exposed by Zaalberg et al. [26], and a mean difference is observed for Danish Holstein with $-4.09 \%, 5.07 \%, 8.08 \%,-29.32 \%$, and $-5.49 \%$ and for Danish Jersey with $12.35 \%, 23.71 \%, 17.91 \%,-13.61 \%$, and $-14.49 \%$ for $\mathrm{Na}, \mathrm{Ca}, \mathrm{Mg}$, P, and $\mathrm{K}$, respectively, in comparison to our data.

Table 2. Descriptive statistics value calculated from reference content ( $\mathrm{mg} / \mathrm{kg}$ of milk) analyzed in ICP-AES.

\begin{tabular}{ccccccc}
\hline Mineral & Nsamples & Mean & SD & CV & Min & Max \\
\hline $\mathrm{Na}$ & 1145 & 354.73 & 90.09 & 25.40 & 234.00 & 1273.00 \\
$\mathrm{Ca}$ & 1251 & 1148.40 & 132.96 & 11.58 & 593.40 & 1743.00 \\
$\mathrm{Mg}$ & 1281 & 99.38 & 13.04 & 13.12 & 60.82 & 156.60 \\
$\mathrm{P}$ & 1238 & 990.91 & 126.31 & 12.75 & 508.52 & 1447.00 \\
$\mathrm{~K}$ & 1246 & 1513.83 & 148.88 & 9.83 & 819.15 & 1984.60 \\
\hline
\end{tabular}

\subsection{Creation of Models Predicting Mineral Content in Milk}

The prediction performances of both the different sets of predictive PLS models to determine the major mineral contents in milk are listed in Table 3. Maximum 1181 and 1211 samples were used to design both sets of calibration models. In order to ensure the comparison of results between the two sets of models, the number of LV used for the second set of models was the same as the ones fixed for the first set. The $\Delta_{\text {outlier }}$ has shown that the $\mathrm{T}$ test is mandatory in order to obtain unfalse models. Indeed, the T test decreased RMSE, especially for Ca and P. This decrease was probably due to a bad sampling or a precipitate issue coming from a long freezing time. The validation RPD value allowed us to assess the accuracy and robustness of each prediction equation. Both models had relatively similar cross-validation performances, but in cross-validation, RPD decreased from $-1 \%$ to $-13 \%$ when 30 Austrian samples were added in the training set. However, the validation RPD increased from 6 to $39 \%$, except for $\mathrm{Na}$, where RPD decreased by $-16 \%$. As stated in [27], it validates that inclusion of variability in the dataset can decrease the apparent accuracy (i.e., in cross-validation) but improve the robustness and real performances of the models in validation. It consequently seems important to cover the variability of new samples to predict in order to limit extrapolation and ensure better predictions in routine. Indeed, when the inclusion of Austrian dataset is added, the RMSEP decreases by $1.1 \%$, $12.8 \%, 11.1 \%, 36.7 \%$, and $18.7 \%$ for $\mathrm{Na}, \mathrm{Ca}, \mathrm{Mg}, \mathrm{P}$, and $\mathrm{K}$, respectively.

The main purpose of using different sets of calibration was not to evaluate the model's performance, but more to compare the data influence. Indeed, the data exposed a completely different distribution for both models. Within this study, the main purpose was to establish robust models, which is not classically the main criteria from a statistical point of view. In this specific case, a large coverage of spectral variability which implies that models can be applied in a large panel of cases was the priority. This sought-after robustness allows the model to be used on a larger scale for smart farming. The standard deviation performed with all the samples analysed from ICP-AES exhibited higher SD (Table 2) compared to the models exhibited in Table 3. When some values are too different from each other, the removal of these samples (considered as outliers) helps to minimize prediction errors. 
Table 3. Prediction performances of equations allowing to predict the content $(\mathrm{mg} / \mathrm{kg}$ of milk) of major minerals in bovine milk.

\begin{tabular}{|c|c|c|c|c|c|c|c|c|c|c|c|c|c|}
\hline \multirow[b]{2}{*}{ Subset } & \multirow[b]{2}{*}{ Mineral } & \multirow[b]{2}{*}{ Nsamples } & \multirow[b]{2}{*}{ Noutliers } & \multirow[b]{2}{*}{ LV } & \multirow[b]{2}{*}{$\Delta_{\text {outlier }}$} & \multicolumn{4}{|c|}{ 10-Fold Cross-Validation } & \multicolumn{4}{|c|}{ Validation } \\
\hline & & & & & & RMSEcv & $\mathbf{R}^{2} \mathrm{cv}$ & RPDcv & CCC & RMSEP & $\mathbf{R}^{2} \mathbf{p}$ & RPDp & CCCp \\
\hline \multirow{5}{*}{$\begin{array}{l}\text { Without } \\
\text { Austrian } \\
\text { samples }\end{array}$} & $\mathrm{Na}$ & 1019 & 26 & 13 & 6.41 & 50.98 & 0.44 & 1.34 & 0.63 & 55.19 & 0.36 & 1.24 & 0.58 \\
\hline & $\mathrm{Ca}$ & 1094 & 57 & 10 & 46.22 & 53.38 & 0.82 & 2.34 & 0.90 & 71.74 & 0.78 & 1.74 & 0.81 \\
\hline & $\mathrm{Mg}$ & 1124 & 57 & 11 & 4.28 & 6.53 & 0.72 & 1.88 & 0.85 & 8.11 & 0.51 & 1.51 & 0.68 \\
\hline & $\mathrm{P}$ & 1083 & 55 & 10 & 22.72 & 58.71 & 0.75 & 1.99 & 0.86 & 81.31 & 0.83 & 1.44 & 0.75 \\
\hline & K & 1090 & 56 & 12 & 9.23 & 88.14 & 0.55 & 1.48 & 0.74 & 181.48 & 0.24 & 0.72 & 0.20 \\
\hline \multirow{5}{*}{$\begin{array}{c}\text { With } 30 \\
\text { Austrian } \\
\text { samples } \\
\text { included }\end{array}$} & $\mathrm{Na}$ & 997 & 78 & 13 & 7.65 & 49.05 & 0.43 & 1.16 & 0.58 & 54.56 & 0.33 & 1.04 & 0.54 \\
\hline & $\mathrm{Ca}$ & 1106 & 75 & 10 & 33.04 & 53.52 & 0.81 & 2.31 & 0.90 & 63.63 & 0.77 & 1.94 & 0.84 \\
\hline & $\mathrm{Mg}$ & 1164 & 47 & 11 & 13.81 & 6.87 & 0.69 & 1.79 & 0.83 & 7.30 & 0.55 & 1.69 & 0.72 \\
\hline & $\mathrm{P}$ & 1126 & 42 & 10 & 27.44 & 62.70 & 0.72 & 1.88 & 0.85 & 59.47 & 0.84 & 2.00 & 0.84 \\
\hline & $\mathrm{K}$ & 1120 & 56 & 12 & 8.35 & 91.30 & 0.54 & 1.46 & 0.73 & 152.89 & 0.26 & 0.87 & 0.29 \\
\hline \multirow{5}{*}{$\begin{array}{l}80 \% \text { of } \\
\text { randomly } \\
\text { selected } \\
\text { samples }\end{array}$} & $\mathrm{Na}$ & 886 & 31 & 13 & 17.73 & 54.39 & 0.39 & 1.15 & 0.58 & 62.24 & 0.49 & 1.00 & 0.58 \\
\hline & $\mathrm{Ca}$ & 961 & 41 & 10 & 29.18 & 58.30 & 0.80 & 2.20 & 0.89 & 69.98 & 0.67 & 1.83 & 0.80 \\
\hline & $\mathrm{Mg}$ & 998 & 27 & 11 & 8.51 & 7.18 & 0.66 & 1.70 & 0.81 & 7.78 & 0.69 & 1.57 & 0.79 \\
\hline & $\mathrm{P}$ & 965 & 30 & 10 & 6.49 & 65.04 & 0.71 & 1.85 & 0.84 & 66.97 & 0.72 & 1.79 & 0.84 \\
\hline & $\mathrm{K}$ & 965 & 33 & 12 & 14.27 & 100.17 & 0.48 & 1.36 & 0.74 & 106.69 & 0.52 & 1.28 & 0.66 \\
\hline
\end{tabular}

Nsample $=$ the numbers of samples included in the models, Noutliers = number of discarded sample after the residual analysis, RMSEcv and RMSEP Standard error of cross-validation and validation respectively; CCC $=$ concordance correlation coefficient, RPD $=$ ratio of prediction to deviation, $\Delta_{\text {outlier }}(\%)$ model performance increasing with $\mathrm{T}$ test $(\mathrm{SD}=2.5)$ and none with the same $\mathrm{LV}$.

The residual analysis performed during the calibration process made this job. The models were built in several sample collection phases, where the samples were selected if the predicted value from the previous model was of interest to improve the robustness of the newly created model. However, this data collection method is known to increase the prediction errors of a model [27].

The opposite results in cross-validation and validation show the relevancy of performing a fully independent validation. The RMSEP of validation mentioned in Table 3 confirms the importance of searching for variability to obtain the most robust model, as RMSEP was improved when only 30 Austrian samples were added in the training set. For cattle coming from a totally different environment with different feed rations, different climatic conditions, and different breeds, the milk composition could radically change. For $\mathrm{Na}, \mathrm{Ca}$, and $\mathrm{Mg}$, a slight difference was found between both external validations (Table 3), which explains the model being robust enough to predict the Austrian samples well.

For the P model including Austrian samples in the calibration dataset, a large decrease of the RMSEP of validation was observed, confirming a better performance of the predicted model (i.e., Higher RPD). The relatively high errors of prediction (for both external validation) for the $\mathrm{K}$ model revealed the incapacity of the model to accurately predict the Austrian samples.

When $80 \%$ of samples in the calibration model were randomly chosen, the RMSEP for predicting $\mathrm{K}$ was $106.7 \mathrm{mg} / \mathrm{kg}$. This prediction error seems more consistent (than the validation with only Austrian samples) and confirms the differences from $\mathrm{K}$ content in the Austrian milk sample. These results may be explained by the difficulty to predict the $\mathrm{K}$ content in milk.

Even with a robust model including samples from four different countries, the external validation exhibited some deficiencies to validate Austrian samples for $\mathrm{P}$ and $\mathrm{K}$. A decrease for RMSEP was revealed when 30 samples coming from the Austrian validation set was included in the calibration set. The results obtained in this study highlight the need for data collaboration and the interest of including local variability to obtain the most robust models. The best way to collaborate is to have a common database and standardized spectra allowing to taking into account the machine-dependent errors [29].

Compared to the current study, the models published in the literature $[15,19]$ exhibited similar model performance (RPD) but exhibited higher RMSE. Indeed, the RMSECV 
obtained in the current study were globally lower when compared to a previous study by $-30 \%,-77 \%,-60 \%,+20 \%$, and $-49 \%$ [19] and $-40 \%,-124 \%,-79 \%,-34 \%$, and $-31 \%$ [23] for $\mathrm{Na}, \mathrm{Ca}, \mathrm{Mg}, \mathrm{P}$, and $\mathrm{K}$, respectively. However, it is important to note that the data exposed a completely different distribution in the other studies. Indeed, the results highlighted by the literature $[19,23]$ present a higher mean, and consequently, a greater standard error of prediction. Consequently, it is more relevant to compare the results using the RPD, which is relative to RMSE and SD.

Another approach will be to compare with the CCC metric, but Soyeurt et al. [19] and Visentin et al. [23] did not evaluate their model with this parameter. When the CCC was applied to the cross-validations of our three models, the performance was approximately the same, except for $\mathrm{Na}$ coming from the first models $(8.6 \%)$. The CCC informed us that our models were not subject to bias or slope issues.

Based on the RPD values [36], we can conclude that all models created for Ca and P have the potential for approximate quantitative predictions and screening, whereas the screening for $\mathrm{Na}, \mathrm{Mg}$, and $\mathrm{K}$ seems to be impossible due to the low RPD values of their models. However, the accuracy of those models was enough to discriminate different groups of cows producing high or low contents of minerals in their milk. The poor RPD performance of the model is related, so that the infrared does not directly detect minerals in milk. Indeed, since infrared measures the vibration of binding molecules, the infrared measurement cannot allow a direct detection of possible ions in solutions. The models presented are therefore indirect models.

\subsection{Correlation between Mineral Traits and Traits Related to Animal Health and Milk Technological Properties}

The Pearson correlations were estimated to achieve two objectives. The first one was to compare the reference minerals dataset with the MIR predicted traits, and the second one was to compare the predicted mineral dataset with the MIR predicted traits (Table 4). Since the dataset created to develop the different models was not representative of the population as the selection of samples was not randomly conducted, the correlations given in this study cannot be generalized to the population. However, it was interesting to observe whether the relationships between traits stayed similar when using reference or predicted mineral contents even if the prediction accuracy was not high. Moreover, this allows to confirm the relationships with other predicted traits known to be related to animal health or the milk technological properties.

When comparing the correlation obtained between reference or predicted mineral traits and other MIR predicted traits mentioned in Table 4, the value of correlations had the same trend, but not the same amplitude. Indeed, the correlations between the predicted mineral data generally result in a higher correlation than those using the reference values. This correlations amplification could be mainly explained by the common part of the spectral information shared by all the predicted traits. In order not to exaggerate the reality, the results and discussion will focus on the correlation values between the measured minerals and the predicted features.

Pearson's correlation between the reference mineral contents of milk ranged from -0.27 to 0.55 . Moderate relationships between $\mathrm{Mg}$ and $\mathrm{P}, \mathrm{Ca}$, and $\mathrm{Mg}$, as well as $\mathrm{Ca}$ and $P$ were found with a correlation value of $0.55,0.54$, and 0.49 , respectively. Weak negative relationships were found for $\mathrm{Na}$ and $\mathrm{K}, \mathrm{Ca}$ and $\mathrm{K}$, as well as $\mathrm{Mg}$ and $\mathrm{K}$ with $-0.27,-0.15$, and -0.14 , respectively. It is interesting to notice that the correlation between mineral contents predicted from the calibration set exposed the same trend of relationship (Table 4). 
Table 4. Observed correlations between measured and predicted mineral levels, milk yields ${ }^{1}$ (L), and predicted traits as pFat $^{2}$ (g/100 g), pProteins ${ }^{2}$ (g/100 g), pCasein (g/100 g), pCitrate (mmol/L), pLactose ${ }^{2}$ (g/100 g), pNAGase (Units/L), pLDH (Units/L), pLactoferrin (mg/L) pRCT (s), pk20 (s), pa30 (s), and pFresh ILCY (g curd/100 g).

\begin{tabular}{|c|c|c|c|c|c|c|c|c|c|c|}
\hline \multirow[b]{2}{*}{ Traits } & \multicolumn{5}{|c|}{ Reference Minerals } & \multicolumn{5}{|c|}{ Predicted Minerals } \\
\hline & $\mathbf{N a}$ & $\mathrm{Ca}$ & $\mathrm{Mg}$ & $\mathbf{P}$ & $\mathbf{K}$ & $\mathrm{pNa}$ & $\mathrm{pCa}$ & $\mathrm{pMg}$ & $\mathrm{pP}$ & pK \\
\hline $\mathrm{pNa}$ & 0.68 & 0.08 & 0.12 & $0.04 *$ & -0.15 & & 0.02 & 0.06 & -0.16 & -0.27 \\
\hline $\mathrm{pCa}$ & $0.00 *$ & 0.86 & 0.58 & 0.42 & -0.28 & $0.06^{*}$ & & 0.62 & 0.51 & -0.36 \\
\hline $\mathrm{pMg}$ & $0.06 *$ & 0.61 & 0.81 & 0.53 & $0.03 *$ & $0.16^{*}$ & 0.74 & & 0.62 & -0.15 \\
\hline $\mathrm{pP}$ & $0.00 *$ & 0.44 & 0.53 & 0.82 & -0.18 & 0.03 * & 0.54 & 0.66 & & 0.13 \\
\hline $\mathrm{pK}$ & -0.08 & -0.29 & -0.16 & $0.03 *$ & 0.67 & -0.14 & -0.40 & -0.24 & $0.03 *$ & \\
\hline Milk Yields & -0.13 & -0.19 & -0.22 & -0.10 & 0.28 & -0.15 & -0.21 & -0.27 & -0.12 & 0.32 \\
\hline pFat & $-0.04 *$ & 0.27 & 0.27 & 0.11 & -0.21 & -0.09 & 0.39 & 0.34 & 0.11 & -0.41 \\
\hline pProteins & 0.14 & 0.58 & 0.56 & 0.50 & -0.30 & 0.26 & 0.68 & 0.72 & 0.63 & -0.40 \\
\hline pLactose & -0.41 & $0.07^{*}$ & $-0.08 *$ & 0.07 & $-0.06^{*}$ & -0.69 & 0.073 & -0.09 & 0.10 & -0.11 \\
\hline pCasein & $0.09 *$ & 0.55 & 0.56 & 0.51 & -0.24 & 0.17 & 0.66 & 0.71 & 0.64 & -0.34 \\
\hline pCitrate & -0.04 * & 0.43 & 0.48 & 0.12 & $-0.06^{*}$ & $-0.02 *$ & 0.54 & 0.59 & 0.19 & $-0.07^{*}$ \\
\hline pNAGase & 0.46 & 0.19 & 0.32 & $0.03 *$ & -0.15 & 0.74 & 0.21 & 0.42 & $0.06 *$ & -0.15 \\
\hline pLDH & 0.32 & 0.11 & 0.24 & 0.08 * & -0.12 & 0.54 & 0.15 & 0.34 & 0.00 * & -0.15 \\
\hline pLactoferrin & 0.39 & 0.17 & $0.08 *$ & 0.03 * & -0.25 & 0.62 & 0.18 & 0.13 & 0.04 & -0.29 \\
\hline pRCT & 0.21 & 0.01 * & -0.01 * & -0.01 * & $0.07^{*}$ & 0.323 & -0.06 * & -0.07 * & -0.02 * & $0.09 *$ \\
\hline pk20 & $0.06^{*}$ & -0.21 & -0.25 & -0.37 & $0.09 *$ & 0.098 & -0.30 & -0.46 & -0.28 & 0.15 \\
\hline pa30 & $0.04 *$ & 0.23 & 0.25 & 0.35 & -0.10 & 0.07 * & 0.29 & 0.45 & 0.29 & -0.14 \\
\hline pFresh ILCY & $-0.02 *$ & 0.49 & 0.49 & 0.38 & -0.25 & $-0.02 *$ & 0.61 & 0.58 & 0.41 & -0.43 \\
\hline
\end{tabular}

${ }^{1}$ Real milk yields; ${ }^{2}$ Manufacturer equation Delta Perkin Elmer; ${ }^{*}$ Correlations between traits who are not significant $(p>0.05)$. Correlations above the diagonal between predicted minerals were performed on the large-scale prediction dataset (real population), and correlations below the diagonal between predicted minerals were performed on the calibration dataset; NAGase: $N$-acetyl- $\beta$-D-glucosaminidas; LDH: lactose dehydrogenase; RCT: rennet coagulation time; k20: curd-firming time; a30: curd firmness 30 min after rennet addition; ILCY: Individual laboratory cheese yield.

The caseins were part of the phosphoproteins with $0.85 \%$ of the phosphorous as phosphates. Unlike whey proteins, which do not contain any phosphorous, the phosphates are responsible for the ability to bind a large amount of calcium cations. This type of phosphate coming from the esterification of the hydroxyl group of serine was called organic phosphate [37]. The presence of calcium ions associated with casein led to the formation of casein micelles. This calcium ionic interaction is strongly linked to protein concentration [37]. The analysed minerals were initially found as Calcium or Magnesium Phosphate. As there were counterions (ionic interaction), a strong correlation between these minerals exist (Ca and $\mathrm{P}, \mathrm{Mg}$ and $\mathrm{P}$; Table 4). Magnesium is also involved in many enzymatic reactions. For example, in milk, $\mathrm{Mg}$ is involved with alkaline phosphatase, which has a role of dephosphorylating agents [38].

These phosphorous salts are mainly found inside large colloidal particles of casein under the form of colloidal (nano-clusters) phosphate. Indeed, the phosphorous is distributed within $38.5 \%$ of colloidal inorganic phosphate, $33 \%$ of inorganic salt soluble in milk, $20 \%$ of organic phosphate (casein phosphate), $7 \%$ as organic esters, and $1.5 \%$ of phosphorous lipids [39]. The percentage of the salt included in the micelle was around $6 \%(w / w)[37,40]$, explaining the link between pProteins and $\mathrm{Mg}$ and P found in Table 4. In order to better explain this phenomenon, the method and models developed by Franzoi et al. [24,40] could be used to calculate the correlation between casein and the micellar mineral.

In the aqueous phase of the milk, the bivalent cations could be favorably chelated to citrate to form undissociated complexes. The positive correlation between $\mathrm{pCitrate}$ and $\mathrm{Ca}$ and $\mathrm{Mg}(\mathrm{r}=0.43,0.48$, respectively) could explain the possible chelation.

Increased sodium in milk is a sign of udder infection in cows [41]. Therefore, the sodium comes from a blood transfer with the milk. To maintain a constant osmotic pressure, the synthesis of lactose is reduced $[39,42]$. The Na content was negatively correlated with pLactose (Table 4) confirming this transfer. It has been demonstrated that NAGase is a mastitis marker [43,44]. In this study, a positive correlation between $\mathrm{Na}$ and pNAGase and 
pLDH was found (Table 4) leading to a possible confirmation of the link between sodium and mastitic infection. Moreover, a clear positive correlation was found with pLactoferrin $(r=0.36$ to 0.62$)$, which is also known as a mastitis indicator [34,45].

High Na and low K content in milk were found to be a mastitis indicator [46]. This is in line with the negative correlation observed between these two minerals. Summer et al. [47] revealed the links between $\mathrm{Na}, \mathrm{K}$, and somatic cells confirming that low potassium content is an indicator of clinical mastitis [47]. When milk exhibits a high somatic cell content $(>400,000)$, the Na concentration tends to increase, while the K content tends to drop.

The milk coagulation ability ( $k 20$, a30, and Fresh ILCY) was mainly correlated with $\mathrm{Ca}, \mathrm{Mg}$, and $\mathrm{P}$ (Table 4) and exposed the importance of mineral composition to cheese manufacturing [48]. Sanchez et al. [49] asserted a moderate genetic correlation between Ca, $\mathrm{Mg}$, and $\mathrm{P}$ with fresh curd yield and coagulation traits. No genetic correlation was found with $\mathrm{Na}$ and $\mathrm{K}$. These findings follow the same correlation as our study.

\subsection{Descriptive Statistics Applied on the Walloon Database}

Computations were carried out with scripts developed in R studio 1.2.5033 (RStudio, Inc., Boston, MA, USA) using R statistical software 3.6.2 (R development Core Team 2019). The descriptive statistics derived from the large-scale prediction are shown on the Table 5.

Table 5. Descriptive statistics of large-scale phenotyping on the mid-infrared predictions Walloon database. The means, standard deviation, and minimum and maximum values are expressed in $\mathrm{mg} / \mathrm{kg}$.

\begin{tabular}{cccccc}
\hline Mineral & $\mathbf{N}$ & Mean & SD & Min & Max \\
\hline $\mathrm{Na}$ & $3,510,077$ & 346 & 43 & 200 & 500 \\
$\mathrm{Ca}$ & $3,510,077$ & 1163 & 102 & 900 & 1500 \\
$\mathrm{Mg}$ & $3,510,077$ & 100 & 8 & 80 & 130 \\
$\mathrm{P}$ & $3,510,077$ & 976 & 91 & 700 & 1300 \\
$\mathrm{~K}$ & $3,510,077$ & 1471 & 98 & 1100 & 1700 \\
\hline
\end{tabular}

\subsection{Month Influence on Milk-Predicted Mineral Composition}

The descriptive statistics derived from large-scale prediction from the Walloon DHI database are shown in Table 5. By monthly averaging those results, the annual evolution of concentration of the five main predicted minerals in milk were computed and shown in Figure 1. There were three types of predicted mineral annual tendencies: (1) sodium (2) calcium, magnesium, and phosphorus, and (3) potassium. Predicted sodium increased from February to September, with a slight decrease between May and July. During the year, the lowest amount of $\mathrm{pNa}$ was around February, and the maximum amount around September. A local minimum was observed in July.

The second tendency exposed an annual behavior with a characteristic minimum during the summer and a significant increase between August and September. Although the concentration of $\mathrm{pMg}$ remained mostly stable between October and January, a sharp decrease was observed between December and January. For $\mathrm{pCa}$, a similar plateau was observed between October and December.

The last predicted mineral tendency $(\mathrm{K})$ experienced a sharp decline for a long period of the year between January and October. During this long period of decline, two local minima were observed in March and May, with the strongest decline occurring between April and May. 


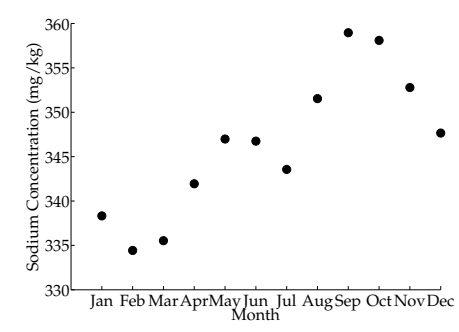

(a) Predicted Sodium

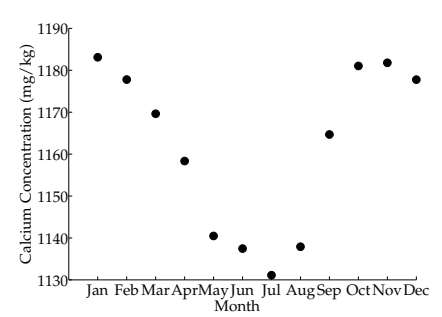

(b) Predicted Calcium

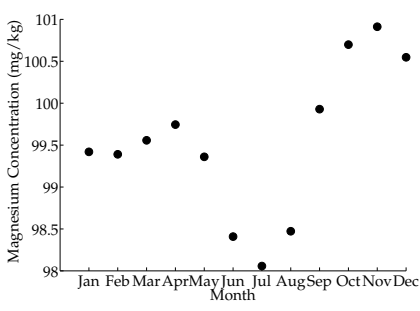

(c) Predicted Magnesium

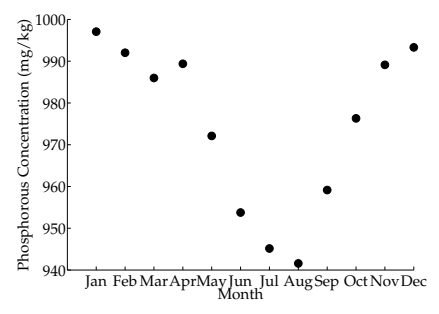

(d) Predicted Phosphorous

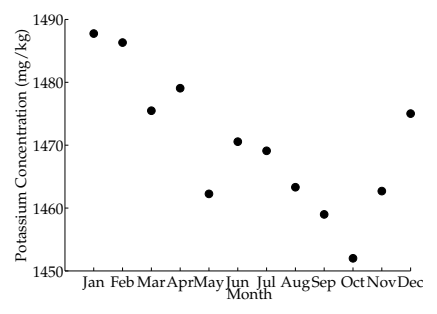

(e) Predicted Potassium

Figure 1. Evolution of predicted minerals in the function of the month when models are applied on a DHI milk spectral database. With a number of observations per month of: January $(n=330,321)$; February $(n=318,414)$; March $(n=318,433)$; April $(n=310,021)$; May $(n=314,933)$; June $(n=302,846)$; July ( $n=139,963)$; August $(n=293,711)$; September $(n=290,688)$; October $(n=291,484)$; November ( $n=298,209)$; December $(n=301,054)$. (a) Predicted Sodium (b) Predicted Calcium (c) Predicted Magnesium (d) Predicted Phosphorous (e) Predicted Potassium.

For $\mathrm{pCa}$ and $\mathrm{pP}$, the concentration followed the same trend as the fat concentrations depending on the month, as shown by Zhang et al. [50], while pMg was more similar to the proteins aspect. Bittante et al. [51] has also shown that the proteins and the fat in milk decrease during the summer. Thus, the predicted minerals $\mathrm{Ca}, \mathrm{Mg}$, and $\mathrm{P}$ followed an identical pathway.

Diet is a key factor in explaining this behavior: throughout the year, the diet can change radically. In the studied region, during the summer, the livestock were mainly on pastures, and little supplementary feed (concentrate, silage, etc.) was given, resulting in a lower proportion of fat and protein. Grazing is also susceptible to modify the cation/anion balance of the diet, which affects the body mineral balance [52]. Another important change during the summer is the increase in temperature. This heat stress had a negative impact on the cow's well-being, leading to underfeeding and therefore a modification of milk composition [50].

In many countries, farmers use group calving at the same time of the year. This induces cows to have the same stage of lactation at the same time, which may explain some of the differences in mineral content throughout the year.

\subsection{Effect of Lactation on Milk-Predicted Minerals}

The mineral content of milk according to the DIM and the parity is shown in Figure 2. Two behaviors were observed, where the first corresponds to an exponential decrease until the lactation peaks, followed by a slight increase in mineral content over the days for $\mathrm{pNa}, \mathrm{pCa}, \mathrm{pMg}$, and $\mathrm{pP}$. This trend showed the opposite behavior of milk production. The second behavior corresponds to a slight increase in $\mathrm{K}$ content up to the maximum (different according to parity), followed by a slight decrease over the DIM. In agreement with Table 4 , potassium was positively correlated with milk yields $(r=0.32)$. A decrease through the parities was observed for mineral elements (except for $\mathrm{pNa}$ and $\mathrm{pCa}$ ) with a larger gap between the first and second parity. 


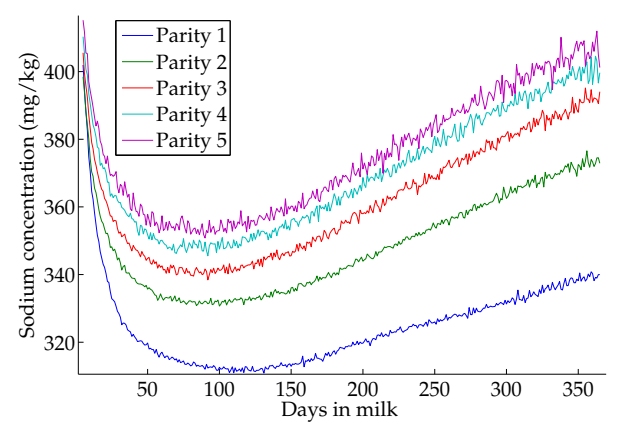

(a) Predicted Sodium

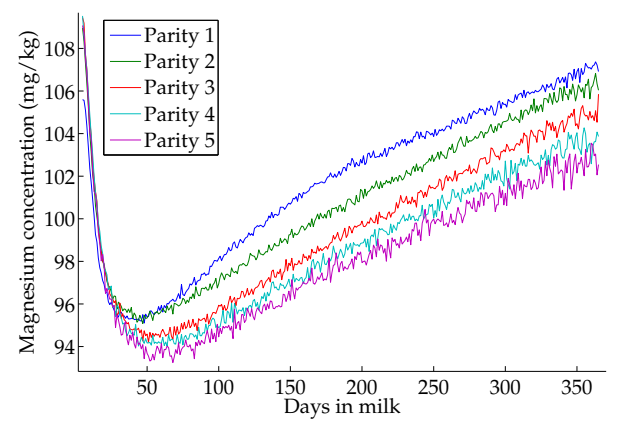

(c) Predicted Magnesium

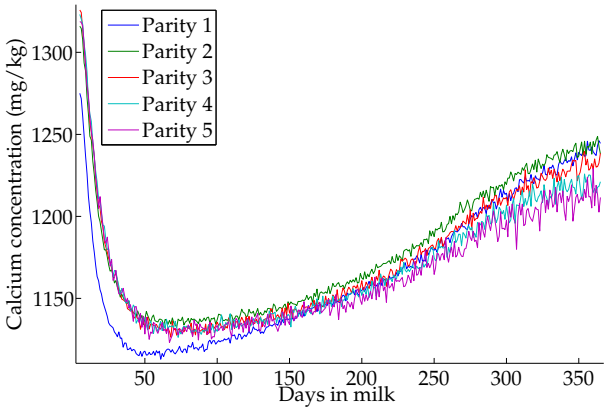

(b) Predicted Calcium

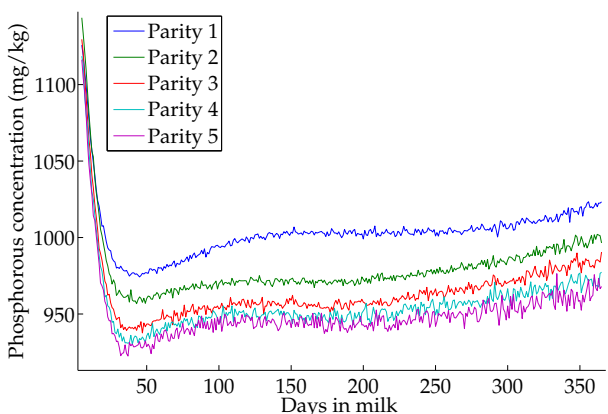

(d) Predicted Phosphorous

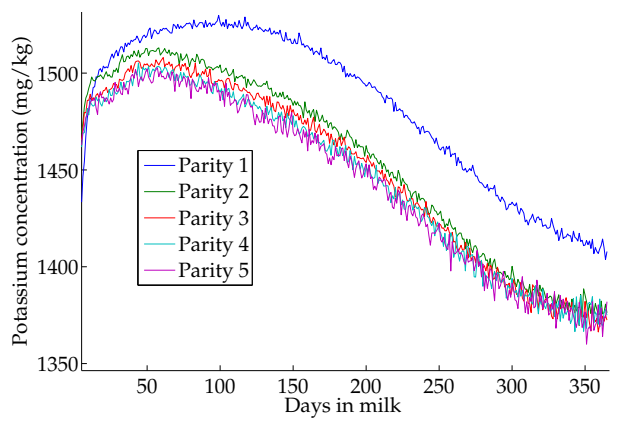

(e) Predicted Potassium

Figure 2. Evolution of the predicted mineral concentration through the days in milk and parity. (a) Predicted Sodium (b) Predicted Calcium (c) Predicted Magnesium (d) Predicted Phosphorous (e) Predicted Potassium.

Analyses of DIM and parity has already been done by different authors [53,54], but these studies focused on the breed and not on a global aspect. Our study has provided a new observation of the mineral concentration depending on the DIM and the parity around 10,000 spectra per days in milk on the first five parities of the cattle. The sharp decrease in mineral traits (except $\mathrm{pK}$ ) at the beginning of DIM was probably the result of a dilution effect, where the onset of milk yields was indeed very low. The increase of minerals, except for $\mathrm{pK}$, throughout lactation could also be derived from a dilution effect in milk. Moreover, Holt et al. [55] mentioned a rise in casein level in late lactation, leading to a higher content of $\mathrm{Ca}$ and $\mathrm{Mg}$, and Kume and Tanabe [56] and Visentin et al. [53] mentioned a similar degressive trend for $\mathrm{pCa}, \mathrm{pMg}$, and $\mathrm{pP}$ content across parity. Or as in the first parity of cows, the skeleton may not be completely structured, and calcium could be more mobilized for bone fixation instead of calf feeding, explaining the minimum at the beginning and the 
progressive increase until it is higher than the Ca present in the milk for multiparous cows through the DIM.

A link between mastitis infection and sodium was clearly identified based on the estimated correlations with mastitis indicators (Table 4). The increase in sodium across parity could be explained by the fact that the more cows age, the SCC tends to increase, and the more likely they are to have an udder infection [57,58]. Finally, there was an increase in sodium across lactation, as the increase in SCC is due to the innate immune response of the animal in preparation for calving, and to reinforce the defense mechanism of the mammary gland at this critical period of calving [59] so the sodium would follow the trend of SCC. The correlation between minerals and NAGase could be a good indicator to detect mastitides in dairy cattle.

\section{Conclusions}

In conclusion, this study developed new predictive equations for $\mathrm{Na}, \mathrm{Ca}, \mathrm{Mg}, \mathrm{P}$, and $\mathrm{K}$ in milk from a large dataset, including records coming from multiple countries. The robustness of these equations was also demonstrated by external country validations in Austrian samples. The importance of including local variability in the model was tested by integrating 30 Austrian samples in the calibration dataset and validating with the remaining samples. Despite relatively good RMSEP for the model without the addition of the Austrian samples, RMSEP tends to decrease with the addition of the Austrian samples. This work shows the usefulness of including local variability to improve the robustness of a prediction equation.

The correlation values exhibited strong links between $\mathrm{Ca}, \mathrm{Mg}$, and $\mathrm{P}$ and confirmed the interactions between these minerals and the protein content in milk. The link between $\mathrm{pNa}$ and mastitis infection was also confirmed based on the estimated correlations.

Large-scale phenotyping allowed to observe the averaged trends of predicted minerals through the year, the parity, and the days in milk. The concentration of the predicted minerals throughout the year were mainly dependent on the feeding. The predicted mineral concentration tended to decrease through the parity (except for $\mathrm{pNa}$ ) and increase within the lactation showing an inverse behavior of the milk yields (except for $\mathrm{K}$ ).

Finally, the potential of mineral profile could be used as a biomarker at an individual level to monitor udder health or technological properties and potentially improve through diet or genetics.

Author Contributions: Conceptualization, O.S.C., C.G. and H.S.; methodology, O.S.C., C.G., F.D. and H.S.; collected data, C.B., D.V., C.L., P.H., A.W., F.-J.A. and N.G.; models creation, O.S.C. and C.G.; large scale prediction, O.S.C. and H.S.; writing-review and editing O.S.C., C.G. and H.S.; supervision, N.G., F.D. and H.S.; funding acquisition, N.G. and F.D. All authors have read and agreed to the published version of the manuscript.

Funding: The authors would like to thank the Walloon Region and European Union's INTERREG NWE program for their financial support of through OptiMIR and Happymoo project, as well as the FFG, Federal Ministry Republic of Austria, Digital and Economic Affairs, and the Federal Ministry Republic of Austria, Climate Action, Environment, Energy, Mobility, Innovation and Technology of Austria for their financial support through the D4Dairy project. This research received a partial financial support from the European Commission, Directorate-General for Agriculture and Rural Development, under Grant Agreement 211708 and from the Commission of the European Communities through the ROBUSTMILK project (Grant Agreement 211708, FP7, KBBE-2007-1). The content of this paper is the sole responsibility of the authors, and it does not necessarily represent the views of the Commission or its services.

Acknowledgments: The authors would like to thank the milk laboratory from the agronomic research center for the highly precious work and their technical Support: Mathieu Dubuisson, Olivier Genard, Petimat Kitaeva and Mohamed El Morabit. And the authors would especially like to thank Okoma Mbelo for performing all the ICP-AES analysis.

Conflicts of Interest: The authors declare no conflict of interest. 


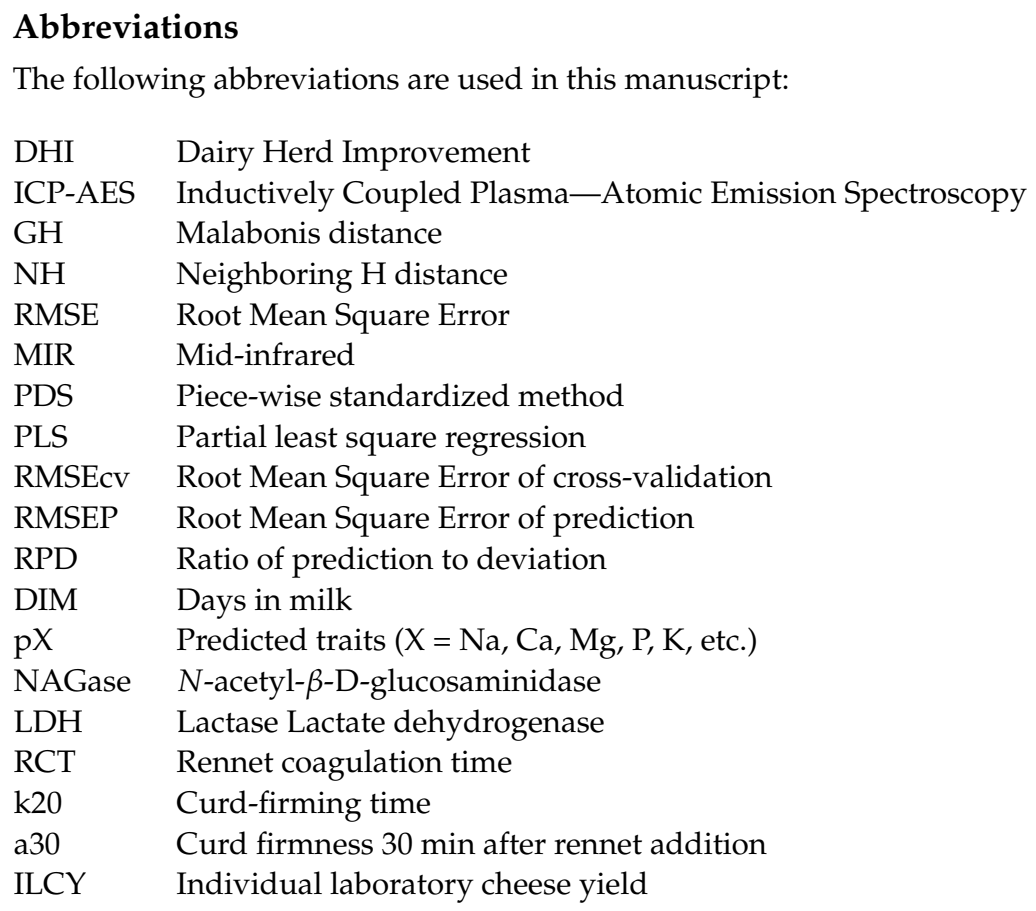

\section{References}

1. Zamberlin, Š.; Antunac, N.; Havranek, J.; Samaržija, D. Mineral elements in milk and dairy products. Mljekarstvo 2012, 62, 111-125.

2. FAO. The State of Food and Agriculture 2001; Number 33; FAO: Rome, Italy, 2001.

3. Guéguen, L.; Pointillart, A. The Bioavailability of Dietary Calcium. J. Am. Coll. Nutr. 2000, 19, 119S-136S. [CrossRef] [PubMed]

4. Huth, P.J.; DiRienzo, D.B.; Miller, G.D. Major Scientific Advances with Dairy Foods in Nutrition and Health. J. Dairy Sci. 2006, 89, 1207-1221. [CrossRef]

5. Lanou, A.J.; Berkow, S.E.; Barnard, N.D. Calcium, Dairy Products, and Bone Health in Children and Young Adults: A Reevaluation of the Evidence. Pediatrics 2005, 115, 736-743. [CrossRef] [PubMed]

6. He, F.J.; MacGregor, G.A. Beneficial effects of potassium on human health. Physiol. Plant. 2008, 133, 725-735. [CrossRef] [PubMed]

7. Whelton, P.K.; He, J. Health effects of sodium and potassium in humans. Curr. Opin. Lipidol. 2014, 25, 75-79. [CrossRef] [PubMed]

8. Uribarri, J.; Calvo, M.S. Dietary phosphorus intake and health. Am. J. Clin. Nutr. 2014, 99, 247-248. [CrossRef]

9. Thachepan, S.; Li, M.; Mann, S. Mesoscale crystallization of calcium phosphate nanostructures in protein (casein) micelles. Nanoscale 2010, 2, 2400-2405. [CrossRef]

10. Zhang, Z.P.; Aoki, T. Behaviour of calcium and phosphate in bovine casein micelles. Int. Dairy J. 1996, 6, 769-780. [CrossRef]

11. Fossa, E.; Pecorari, M.; Sandri, S.; Tosi, F.C.L.C.; Mariani, P.P.U.I.I.d.Z. The Role of Milk Casein Content in the Parmigiano-Reggiano Cheese Production: Chemical Composition-Rennet Coagulation Properties and Dairy-Technological Behaviour of Milk; Scienza e Tecnica Lattiero-Caseari: Parma, Italy, 1994; ISSN 0390-6361.

12. Auldist, M.; Hubble, I. Effects of mastitis on raw milk and dairy products. Aust. J. Dairy Technol. 1998, 53, 28.

13. Hamann, J.; Krömker, V. Potential of specific milk composition variables for cow health management. Livest. Prod. Sci. 1997, 48, 201-208. [CrossRef]

14. Qayyum, A.; Khan, J.A.; Hussain, R.; Avais, M.; Ahmad, N.; Khan, M.S. Investigation of Milk and Blood Serum Biochemical Profile as an Indicator of Sub-Clinical Mastitis in Cholistani Cattle. Pak. Vet. J. 2016, 36, 275-279.

15. Bastin, C.; Théron, L.; Lainé, A.; Gengler, N. On the role of mid-infrared predicted phenotypes in fertility and health dairy breeding programs. J. Dairy Sci. 2016, 99, 4080-4094. [CrossRef] [PubMed]

16. Sarkhot, D.V.; Ghezzehei, T.A.; Berhe, A.A. Effectiveness of Biochar for Sorption of Ammonium and Phosphate from Dairy Effluent. J. Environ. Qual. 2013, 42, 1545-1554. [CrossRef]

17. Kurzbaum, E.; Bar Shalom, O. The potential of phosphate removal from dairy wastewater and municipal wastewater effluents using a lanthanum-modified bentonite. Appl. Clay Sci. 2016, 123, 182-186. [CrossRef]

18. CBS. Phosphate Output from Livestock Manure Down Again. 2019. Available online: https://www.cbs.nl/en-gb/news/2019/0 7 / phosphate-output-from-livestock-manure-down-again (accessed on 2 June 2021).

19. Soyeurt, H.; Bruwier, D.; Romnee, J.M.; Gengler, N.; Bertozzi, C.; Veselko, D.; Dardenne, P. Potential estimation of major mineral contents in cow milk using mid-infrared spectrometry. J. Dairy Sci. 2009, 92, 2444-2454. [CrossRef]

20. Toffanin, V.; De Marchi, M.; Lopez-Villalobos, N.; Cassandro, M. Effectiveness of mid-infrared spectroscopy for prediction of the contents of calcium and phosphorus, and titratable acidity of milk and their relationship with milk quality and coagulation properties. Int. Dairy J. 2015, 41, 68-73. [CrossRef] 
21. Gottardo, P.; De Marchi, M.; Cassandro, M.; Penasa, M. Technical note: Improving the accuracy of mid-infrared prediction models by selecting the most informative wavelengths. J. Dairy Sci. 2015, 98, 4168-4173. [CrossRef]

22. Bonfatti, V.; Degano, L.; Menegoz, A.; Carnier, P. Short communication: Mid-infrared spectroscopy prediction of fine milk composition and technological properties in Italian Simmental. J. Dairy Sci. 2016, 99, 8216-8221. [CrossRef]

23. Visentin, G.; Penasa, M.; Gottardo, P.; Cassandro, M.; De Marchi, M. Predictive ability of mid-infrared spectroscopy for major mineral composition and coagulation traits of bovine milk by using the uninformative variable selection algorithm. J. Dairy Sci. 2016, 99, 8137-8145. [CrossRef]

24. Franzoi, M.; Niero, G.; Penasa, M.; De Marchi, M. Development of Infrared Prediction Models for Diffusible and Micellar Minerals in Bovine Milk. Animals 2019, 9, 430. [CrossRef] [PubMed]

25. Fleming, A.; Schenkel, F.S.; Ali, R.A.; Corredig, M.; Carta, S.; Gregu, C.M.; Malchiodi, F.; Macciotta, N.P.P.; Miglior, F. Phenotypic investigation of fine milk components in bovine milk and their prediction using mid-infrared spectroscopy. Can. J. Anim. Sci. 2018, 99, 218-227. [CrossRef]

26. Zaalberg, R.; Poulsen, N.; Bovenhuis, H.; Sehested, J.; Larsen, L.; Buitenhuis, A. Genetic analysis on infrared-predicted milk minerals for Danish dairy cattle. J. Dairy Sci. 2021, 104, 8947-8958. [CrossRef]

27. Grelet, C.; Dardenne, P.; Soyeurt, H.; Fernandez, J.A.; Vanlierde, A.; Stevens, F.; Gengler, N.; Dehareng, F. Large-scale phenotyping in dairy sector using milk MIR spectra: Key factors affecting the quality of predictions. Methods 2020, 186, 97-111. [CrossRef]

28. Zhang, L.; Li, C.; Dehareng, F.; Grelet, C.; Colinet, F.; Gengler, N.; Brostaux, Y.; Soyeurt, H. Appropriate Data Quality Checks Improve the Reliability of Values Predicted from Milk Mid-Infrared Spectra. Animals 2021, 11, 533. [CrossRef] [PubMed]

29. Grelet, C.; Fernández Pierna, J.A.; Dardenne, P.; Baeten, V.; Dehareng, F. Standardization of milk mid-infrared spectra from a European dairy network. J. Dairy Sci. 2015, 98, 2150-2160. [CrossRef]

30. Murcia, M.A.; Vera, A.; Martinez-Tome, M.; Munoz, A.; Hernandez-Cordoba, M.; Ortiz-Gonzalez, R. Fast Determination of the $\mathrm{Ca}, \mathrm{Mg}, \mathrm{K}, \mathrm{Na}$ and $\mathrm{Zn}$ Contents in Milk and Nondairy Imitation Milk Using ICP-AES without Mineralization Stage. Food Sci. Technol. 1999, 32, 175-179. [CrossRef]

31. Rousseeuw, P.J.; Debruyne, M.; Engelen, S.; Hubert, M. Robustness and outlier detection in chemometrics. Crit. Rev. Anal. Chem. 2006, 36, 221-242. [CrossRef]

32. Grelet, C.; Bastin, C.; Gelé, M.; Davière, J.B.; Johan, M.; Werner, A.; Reding, R.; Pierna, J.F.; Colinet, F.; Dardenne, P.; et al. Development of Fourier transform mid-infrared calibrations to predict acetone, $\beta$-hydroxybutyrate, and citrate contents in bovine milk through a European dairy network. J. Dairy Sci. 2016, 99, 4816-4825. [CrossRef]

33. van der Voet, H. Comparing the predictive accuracy of models using a simple randomization test. Chemom. Intell. Lab. Syst. 1994, 25, 313-323. [CrossRef]

34. Soyeurt, H.; Grelet, C.; McParland, S.; Calmels, M.; Coffey, M.; Tedde, A.; Delhez, P.; Dehareng, F.; Gengler, N. A comparison of 4 different machine learning algorithms to predict lactoferrin content in bovine milk from mid-infrared spectra. J. Dairy Sci. 2020, 103, 11585-11596. [CrossRef]

35. Colinet, F.; Troch, T.; Baeten, V.; Dehareng, F.; Dardenne, P.; Sindic, M.; Gengler, N. Genetic variability of MIR predicted milk technological properties in Walloon dairy cattle. In Book of Abstracts of the 66th Annual Meeting of the European Federation of Animal Science; Wageningen Academic Publishers: Wageningen, The Netherlands, 2015; p. 400.

36. Saeys, W.; Mouazen, A.; Ramon, H. Potential for Onsite and Online Analysis of Pig Manure using Visible and Near Infrared Reflectance Spectroscopy. Biosyst. Eng. 2005, 91, 393-402. [CrossRef]

37. Fox, P.; Uniacke-Lowe, T.; McSweeney, P.; O'Mahony, J. Milk proteins. In Dairy Chemistry and Biochemistry; Springer: Cham, Switzerland, 2015; pp. 145-239.

38. Oh, H.E.; Deeth, H.C. Magnesium in milk. Int. Dairy J. 2017, 71, 89-97. [CrossRef]

39. Fox, P.; Uniacke-Lowe, T.; McSweeney, P.; O'Mahony, J. Salts of milk. In Dairy Chemistry and Biochemistry; Springer: Cham, Switzerland, 2015; pp. 241-270.

40. Franzoi, M.; Niero, G.; Penasa, M.; Cassandro, M.; De Marchi, M. Technical note: Development and validation of a new method for the quantification of soluble and micellar calcium, magnesium, and potassium in milk. J. Dairy Sci. 2018, 101, 1883-1888. [CrossRef] [PubMed]

41. Batavani, R.; Asri, S.; Naebzadeh, H. The effect of subclinical mastitis on milk composition in dairy cows. Iran. J. Vet. Res. 2007, 8, 205-211.

42. Pyörälä, S. Indicators of inflammation in the diagnosis of mastitis. J. Vet. Res. 2003, 34, 565-578. [CrossRef]

43. Kitchen, B.J.; Kwee, W.S.; Middleton, G.; Andrews, R.J. Relationship between the level of $N$-acetyl- $\beta$-D-glucosaminidase (NAGase) in bovine milk and the presence of mastitis pathogens. J. Dairy Res. 1984, 51, 11-16. [CrossRef]

44. Hovinen, M.; Simojoki, H.; Pösö, R.; Suolaniemi, J.; Kalmus, P.; Suojala, L.; Pyörälä, S. N-acetyl-[...]-D-glucosaminidase activity in cow milk as an indicator of mastitis. J. Dairy Res. 2016, 83, 219. [CrossRef] [PubMed]

45. Soyeurt, H.; Bastin, C.; Colinet, F.; Arnould, V.R.; Berry, D.P.; Wall, E.; Dehareng, F.; Nguyen, H.; Dardenne, P.; Schefers, J.; et al. Mid-infrared prediction of lactoferrin content in bovine milk: Potential indicator of mastitis. Animal 2012, 6, 1830-1838. [CrossRef]

46. Norberg, E. Electrical conductivity of milk as a phenotypic and genetic indicator of bovine mastitis: A review. Livest. Prod. Sci. 2005, 96, 129-139. [CrossRef]

47. Summer, A.; Franceschi, P.; Malacarne, M.; Formaggioni, P.; Tosi, F.; Tedeschi, G.; Mariani, P. Influence of somatic cell count on mineral content and salt equilibria of milk. Ital. J. Anim. Sci. 2010, 8, 435-437. [CrossRef] 
48. Lucey, J.; Fox, P. Importance of Calcium and Phosphate in Cheese Manufacture: A Review. J. Dairy Sci. 1993, 76, $1714-1724$. [CrossRef]

49. Sanchez, M.; El Jabri, M.; Minéry, S.; Wolf, V.; Beuvier, E.; Laithier, C.; Delacroix-Buchet, A.; Brochard, M.; Boichard, D. Genetic parameters for cheese-making properties and milk composition predicted from mid-infrared spectra in a large data set of Montbéliarde cows. J. Dairy Sci. 2018, 101, 10048-10061. [CrossRef]

50. Zhang, L.; Gengler, N.; Dehareng, F.; Colinet, F.; Froidmont, E.; Soyeurt, H. Can We Observe Expected Behaviors at Large and Individual Scales for Feed Efficiency-Related Traits Predicted Partly from Milk Mid-Infrared Spectra? Animals 2020, 10, 873. [CrossRef]

51. Bittante, G.; Cipolat-Gotet, C.; Malchiodi, F.; Sturaro, E.; Tagliapietra, F.; Schiavon, S.; Cecchinato, A. Effect of dairy farming system, herd, season, parity, and days in milk on modeling of the coagulation, curd firming, and syneresis of bovine milk. J. Dairy Sci. 2015, 98, 2759-2774. [CrossRef]

52. Cuvelier, C.; Dufrasne, I. L'alimentation de la vache laitiere aliments, calculs de ration, indicateurs d'évaluation des déséquilibres de la ration et pathologies d'origine. Livret Agric. 2005, 22, 1-100.

53. Visentin, G.; Penasa, M.; Niero, G.; Cassandro, M.; De Marchi, M. Phenotypic characterisation of major mineral composition predicted by mid-infrared spectroscopy in cow milk. Ital. J. Anim. Sci. 2018, 17, 549-556. [CrossRef]

54. Manuelian, C.L.; Penasa, M.; Visentin, G.; Zidi, A.; Cassandro, M.; De Marchi, M. Mineral composition of cow milk from multibreed herds. Anim. Sci. J. 2018, 89, 1622-1627. [CrossRef]

55. Holt, C.; Carver, J.; Ecroyd, H.; Thorn, D. Invited review: Caseins and the casein micelle: Their biological functions, structures, and behavior in foods. J. Dairy Sci. 2013, 96, 6127-6146. [CrossRef]

56. Kume, S.I.; Tanabe, S. Effect of Parity on Colostral Mineral Concentrations of Holstein Cows and Value of Colostrum as a Mineral Source for Newborn Calves. J. Dairy Sci. 1993, 76, 1654-1660. [CrossRef]

57. Beckely, M.; Johnson, T. Five year study of California mastitis test testing on a commercial dairy herd. J. Dairy Sci. 1966, 49, 746.

58. Blackburn, P. The variation in the cell count of cow's milk throughout lactation and from one lactation to the next. J. Dairy Res. 1966, 33, 193-198. [CrossRef]

59. Sharma, N.; Singh, N.; Bhadwal, M. Relationship of somatic cell count and mastitis: An overview. Asian Australas. J. Anim. Sci. 2011, 24, 429-438. [CrossRef] 